\title{
ANALISIS HIGH ORDER THINKING SKILLS (HOTS) TAKSONOMI MENGANALISIS PERMASALAHAN FISIKA
}

\author{
Syaiful Rochman ${ }^{1}$, Zainal Hartoyo ${ }^{2}$ \\ Fakultas Keguruan dan Ilmu Pendidikan Universitas Bengkulu ${ }^{1}$ \\ Fakultas Tarbiyah dan Keguruan Universitas Islam Negeri Sulthan Thaha Saifuddin Jambi ${ }^{2}$ \\ srochman@unib.ac.id ${ }^{1}$ \\ Submit, 02-06-2018 Accepted, 16-06-2018 Publish, 23-06-2018
}

\begin{abstract}
The purpose of this research is to get the measurement result as a description of higher order thinking skill in taxonomy to analyze physics problem in SMA XI class. This study is descriptive qualitative through three stages, namely: initial development of the instrument, content validation and empirical, and measurement. The research has been conducted in the region of Central Bengkulu Regency. The instrument used has been validated by the expert. An empirical valiadation test was conducted by 95 students. A valid instrument is used to measure student's higher order thinking skills. The number of learners measured using a total sampling of 148 learners. The measurement result shows very high analyze ability 1 student or 0,5\%, ability analyze high 59 student or 40\%, ability analyze analyze 62 student or $42 \%$, ability analyze low 25 student or 17\%, ability analyze very low 1 student or 0, 5\%. On the average it can be concluded that higher order thinking skills on taxonomy analyze students in Bengkulu Tengah included in medium criterion.
\end{abstract}

Keyword: HOTS, Analyze, Physics

\begin{abstract}
Abstrak: Tujuan penelitian adalah mendapatkan hasil pengukuran sebagai gambaran higher order thinking skills pada taksonomi menganalisis permasalahan fisika di SMA kelas XI. Penelitian ini adalah deskriptif kualitatif melalui tiga tahapan, yakni: pengembangan awal instrumen, validasi isi dan empiris, dan pengukuran. Penelitian telah dilaksanakan di wilayah Kabupaten Bengkulu Tengah. Instrumen yang digunakan telah divalidasi oleh ahli. Uji coba valiadasi secara empiris dilaksanakan oleh 95 siswa. Instrument yang sudah valid digunakan untuk mengukur higher order thinking skills siswa. Jumlah siswa yang diukur menggunakan total sampling sebanyak 148 siswa. Hasil pengukuran menunjukkan kemampuan menganalisis sangat tinggi 1 siswa atau 0,5\%, kemampuan menganalisis tinggi 59 siswa atau 40\%, kemampuan menganalisis sedang 62 siswa atau 42\%, kemampuan menganalisis rendah 25 siswa atau $17 \%$, kemampuan menganalisis sangat rendah 1 siswa atau 0,5\%. Secara rata-rata dapat disimpulkan bahwa higher order thinking skills pada taksonomi menganalisis siswa di Kabupaten Bengkulu Tengah termasuk dalam kreteria sedang.
\end{abstract}

Katakunci: HOTS, Menganalisis, Fisika

\section{PENDAHULUAN}

Kurikulum 2013 menginginkan kemampuan Sumber Daya Manusia (SDM) yang memiliki kualitas tinggi. Dengan kemampuan tersebut, diharapkan mampu bersaing pada abad 21 dan industrilisasi 4.0 di era globalisasi. Mengantisipasi tuntutan tersebut, pendidikan dirancang untuk meningkatkan kinerja yang berkualitas tinggi melalui proses pembelajaran.
Manusia sebagai makhluk yang selalu berproses dan memiliki metode dalam beraktivitas. Salah satu aktivitas manusia yang relevan dengan metode adalah berpikir. Kegiatan berpikir pada umumnya indentik dengan belajar. Secara sederhana aktivitas belajar di Indonesia terjadi di sekolah. Untuk mencapai tujuan yang diinginkan dengan baik, maka guru akan memberikan aktivitas pembelajaran yang mendukung. Dalam aktivitas belajar tersebut, salah satu tugas seorang guru 
adalah mengajarkan cara berpikir. Hasil dari proses pembelajaran tersebut dapat dinilai sebagai prestasi.

Berdasarkan data Programme for International Students Assessment (PISA) yang dirilis oleh the Organisation for Economic Co-operation and Development (OECD) (2016) menunjukkan bahwa kemampuan siswa Indonesia secara berturut-urut untuk kemampuan sains, membaca, dan matematika ada pada peringkat 62, 61, dan 63 dari 69 negara yang dievaluasi. Selanjutnya data Trends International Mathematics and Science Study (TIMSS) (2016) menunjukkan bahwa kemampuan Indonesia dalam sains dan matamatik secara berturut-turut ada pada peringkat 48 dan 45 dari 50 negara peserta dengan skor rata-rata keduanya 39 poin dari 500 poin.

Kebiasaan berpikir tingkat rendah atau low order thingking yang diajarkan kepada siswa menyebabkan tidak memiliki high order thingking skills (HOTS). Seharusnya HOTS diperlukan untuk menyelesaikan persoalan-persoalan secara kreatif, dan inovatif. Guna mengatasi persolan tersebut, siswa tingkat SMA perlu diarahkan untuk mengembangkan HOTS. Dalam konteks pengembangan fisika, siswa perlu dibiasakan untuk menggunakan HOTS.

Gardner (2013) mengatakan unsur terpenting dalam pembelajaran fisika adalah mendukung dan memotivasi siswa agar belajar aktif. Hal tersebut diperkuat dengan pendapat Arwood (2011) menyatakan bahwa berpikir bisa menghubungkan dari satu konsep ke konsep lain dengan rangkaian berpikir, berbicara, membaca, menulis, melihat, mendengarkan, dan menghitung.

Brookhart (2010) mendefinisikan HOTS sebagai proses transfer dari sebuah masalah kemudian masalah tersebut dicari solusinya menggunakan cara berpikir kritis. Secara terpisah Anderson dan Krathwohl's Taksonomi (2010) merevisi level kognitif tersebut menjadi dua, yaitu; cara berpikir tingkat rendah (lower order thiking) terdapat pada level mengingat (C1), memahami (C2), dan mengaplikasikan (C3), sedangkan cara berpikir HOTS berada pada tingkatan menganalisis (C4), mengevaluasi (C5), serta mencipta (C6). Costa (1991) menyampaikan bahwa dalam HOTS dibagi menjadi empat golongan, yaitu memecahkan masalah, membuat keputusan, berpikir kritis, dan berpikir kreatif. Bogan (2005) menemukan HOTS akan terjadi ketika individu menerima informasi asing dan "memanggil" informasi lama yang tersimpan dalam memori.

Menganalisis merupakan proses yang melibatkan bagian dan struktur pemikiran secara keseluruhan untuk memecahan masalah. Menganalisis meliputi proses kognitif mengatribusikan, membedakan, dan mengorganisasi. Nama lain dari menganalisis adalah mengklasifikasikan Jennifer \& Ross (2012) mengatakan bahwa dalam kegiatan mengklasifikasikan siswa akan lebih detail dalam menjelaskan konsep, ciri, dan deskripsi tertentu yang bersifat kebendaan atau nyata.

Membedakan merupakan salah satu kemampuan memilih bagian yang relevan dari sebuah struktur tertentu. Pada saat terjadi proses membedakan pada siswa maka akan terjadi pemerhatian dan pemfokusan antara materi yang relevan dan yang tidak relevan. Kemampuan membedakan dapat dilihat dari soal tes yang dilakukan berupa jawaban singkat atau pilihan. Dalam sebuah jawaban singkat, siswa diberi sebuah kalimat matematis dan diminta untuk menunjukan bagian-bagian mana yang paling penting atau relevan.

Mengorganisasi juga dapat dikatakan sebagi bentuk dari memadukan atau menstrukturkan. Pada saat terjadi proses mengorganisasi siswa akan mengkonstruksi rangkaian yang sistematis setiap potongan informasi. Format 
penilaian dalam mengorganisasi bisa berupa pilihan atau jawaban singkat. Pada soal pilihan, siswa diminta memilih satu kebenaran dari empat struktur organisasi yang paling sesuai dengan organisasi yang dipaparkan. Dengan proses tersebut, siswa lebih mudah dalam mengidentifikasi dan pengenalan struktur akan menjadi lebih mudah.

Mengatribusikan merupakan sudut pandang dari pendengar atau siswa tentang objek yang ditangkap oleh indra manusia. Dalam proses mengatribusikan, siswa memiliki cara pemikiran dan penyampaian ulang yang berbeda-beda, namun memiliki kesimpulan yang sama. Pembuatan dan pemilihan sebuah gambaran yang berbentuk sudut pandang bisa dijadikan sebagai bentuk penilaian dalam mengatribusikan. Pada proses ini siswa akan terbantu dalam memecahkan masalah dengan caranya sendiri. Jennifer \& Ross (2012) yang menemukan bahwa kemampuan mengatribusikan dapat membantu siswa dalam memecahkan masalah. Kemampuan mengatribusikan penting karena menjadi penghubung sebab dan akibat.

Rianawati (2011) menyampaikan bahwa profil HOTS siswa dapat diketahui dengan menguji siswa dalam hal memecahkan masalah yang disajikan dalam bentuk tes. Untuk itu, diperlukan soal-soal yang termasuk Higher Level Question (HLQ). Miri, David, \& Uri (2007) mengungkapkan bahwa "if one persistently teaches for enhancing higherorder thinking skills, there are chances for success", Artinya adalah apabila kita mengajarkan terus menerus mengenai perangkat HOTS maka siswa besar kemungkinan mencapai kesuksesan.

Maka dari itu penilaian dapat memberikan rangsangan kepada siswa dalam mengembangkan kemampuan HOTS. Selanjutnya Nitko dan Brookhart (2011) mendefinisikan pada sebuah penilaian merupakan kegiatan untuk memperoleh informasi yang dibutuhkan untuk mengambil keputusan tentang siswa, sistem kurikulum, program pada sekolah, dan kebijakan tertentu.

Tujuan hasil pengukuran HOTS ini adalah mengetahui Highest Level siswa dalam taksonomi menganalisis. Hasil yang didapatkan dalam pengukuran antara lain berdasarkan asal sekolah, dan berdasarkan ranah kognitif taksonomi Bloom (C4) yang meliputi kemampuan membedakan, kemampuan mengorganisir, dan kemampuan mengatribusikan. setelah melakukan pengukuran, akan memberikan masukan dan diiharapkan dapat memperbaiki HOTS pada sistem pembelajaran.

Berdasarkan penjelasan dan uraian sebelumnya, dapat diketahui bahwa penelitian ini dilakukan untuk menggali informasi serta mengidentifikasi HOTS. Penelitian ini memberikan kontribusi dalam Pendidikan. Kontribusi ynag diberikan adalah hasil penilaian (assessment) melalui tes kepada siswa dalam pelaksanaan sistem pembelajaran.

\section{LANDASAN TEORI}

Aktivitas yang paling banyak terjadi dalam proses berpikir adalah kegiatan menghubungkan ilmu pengetahuan yang ada terhadap masalah yang dihadapi. Kohl \& Finkelstein (2008) terdapat perbedaan yang sangat signifikan antara manusia yang terbiasa memecahkan masalah dan belum pernah memecahkan masalah. Esensi yang paling sederhana adalah kemampuan menggunakan panca indra dalam mengkonfirmasi sebuah teori terhadap fakta. Selain itu dalam masa kerja manusia yang terbiasa berpikir dalam memecahkan masalah akan lebih produktif. Selanjutnya Derry (1999) mengungkapkan bahwa seorang ilmuwan bisa membuat sebuah penemuan menggunakan metode ilmiah. Selain mengunakan metode secara ilmiah banyak manusia yang "merenung" untuk mendapatkan pengetahuan. 
Costa (1991) menjelaskan bahwa dalam keadaan berpikir, manusia akan memandang sebuah peristiwa secara menyeluruh atau tidak ada sekat-sekat yang membatasi. Selain itu, manusia yang berpikir akan menjadi reflektif secara berpikir, hal ini menunjukaan bahwa kebiasaan pola-pola pemikirannya akan terbentuk dengan sendirinya. Pada akhirnya setelah manusia berpikir secara menyeluruh dan reflektif maka akan terjadi kreatifitas dalam pemikiran manusia. Selanjutnya Arwood (2011) menyatakan bahwa berpikir mampu menghubungkan dari satu konsep ke konsep lain dengan rangkaian berpikir, berbicara, membaca, menulis, melihat, mendengarkan, dan menghitung.

Pada dasarnya, Kemampuan berpikir akan meningkat apabila dilatih, dikembangkan, dan menambah pengalaman dalam pemikiran sehingga menjadi bermakna. Dalam proses berpikir kemampuan kognitif yang ada dalam masing-masing individu berkembang.

$$
\text { Bloom et.al }
$$

mengembangkan sebuah kontinum untuk mengkategorikan pertanyaan dan tanggapan dalam berpikir. Taksonomi Bloom ini meliputi unsur-unsur berikut, disusun dari terendah ke tingkat tertinggi: 1) pengetahuan: mengingat fakta-fakta tertentu; 2) pemahaman: menggambarkan dengan kata-kata sendiri; 3) aplikasi: menerapkan informasi untuk menghasilkan beberapa hasil; 4) analisis: pengelompokan sesuatu untuk menunjukkan bagaimana itu dipadukan; 5) sintesis: menciptakan, produk asli yang unik; dan 6) evaluasi: membuat keputusan nilai tentang isu-isu. Tiga tingkat pertama dari sistem ini berurusan dengan orde yang lebih rendah kemampuan berpikir yang penting dalam meletakkan dasar bagi pemahaman yang lebih.

Tiga kemampuan terakhir merupakan keterampilan berpikir tingkat tinggi. Anderson \& Krathwohl's Taksonomi (2010) merevisi level kognitif tersebut menjadi dua, yaitu; cara berpikir tingkat rendah (lower order thiking) terdapat pada level mengingat (C1), memahami (C2), dan mengaplikasikan (C3), sedangkan cara berpikir tingkat tinggi (higher order thinking) berada pada tingkatan menganalisis (C4), mengevaluasi (C5), dan mencipta (C6). Tingkatan ini menyiratkan dalam proses pembelajaran, jika peserta didik menggunakan tingkat berpikir yang lebih tinggi, maka kemampuan berpikir tingkat rendah bisa dilakukan dengan baik.

Penyampaian kebenaran ilmu pengetahuan yang bersifat ilmiah tentu saja kita tidak lepas dari penggunaan bahasa dan istilah. Hal itu karena penggunaan bahasa dalam ilmu pengetahuan adalah bagian proses inti yang akan disampaikan. Salah satu penggunaan bahasa dalam proses pembelajaran dalam sains adalah ungkapan pembelajaran fisika. Bahkan istilah-istilah tertentu akan identik sebagai salah satu ciri dalam menyampaikan materi (Williams, 2011).

Mengingat (C1) dalam pandangan kognitif merupakan tingkatan yang paling rendah. Anderson dan Krathwohl's (2010). Kategori mengingat mencakup proses mengenali (recognizing) dan memanggil (recalling). Pemahaman (C2) dalam pendidikan dapat diartikan sebagai kemampuan peserta didik dalam mengartikan konsep yang memadai untuk menyusun materi dan mengurutkan berdasarkan pengetahuanya. Pada kemampuan ini peserta didik harus mampu memilih fakta yang sesuai untuk menjawab pertanyaan dengan cara mengingat pengetahuan yang dimilikinya. Anderson dan Krathwohl's (2010) mengkategorikan kemampuan ini menjadi empat kategori, yaitu kemampuan manafsirkan, kemampuan memberi contoh, kemampuan mengklasifikasikan, kemampuan untuk merangkum, kemampuan menyimpulkan, kemampuan 
membandingkaan, dan kemampuan menjelaskan.

Penerapan (C3), dalam pemecahan masalah seorang peserta didik yang memiliki kemampuan ini akan menerapkan dan menggunakannya. Krathwohl's (2002) mengatakan bahwa "Carrying out or using a procedure in a given situation". Selain itu pada kemampuan ini dibagi menjadi dua kategori, yaitu kemampuan mengambil keputususan atau eksekusi dan kemampuan menggunakan. Pernyataan itu berarti bahwa penerapan merupakan pelaksanakan atau menggunakan prosedur tertentu dalam situasi tertentu pula. Oleh sebab itu, kemampuan mengaplikasikan sangat berkaitan dengan kemampuan prosedural. Kemampuan prosedural pada dasarnya diperoleh kemampuan mengingat dan memahami sesuatu. Setelah mampu menguasai kemampuan prosedural maka peserta didik juga akan mampu menerapkan dan mengimplementasikan.

Kemampuan Menganalisis (C4) dapat diartikan sebagai kemampuan peserta didik menentukan bagian-bagian yang menjadi penyusun suatu bentuk, objek, ataupun masalah tertentu sehingga peserta didik mampu menunjukan keterkaitan satu sama lain. Krathwohl's (2002) membagi kemampuan ini menjadi tiga, yaitu kemampuan membedakan,kemampuanmengorganisasi, dan kemampuan memberikan ciri khusus. Selain itu, beliau mengatakan bahwa "Breaking material into its constituent parts and detecting how the parts relate to one another and to an overall structure or purpose".

Berdasarkan hal itu maka pengertian analisis merupakan memecahkan kosep menjadi bagianbagian penyusunnya dan mengidentifikasi hubungan masing-masing bagian-bagian satu terhadap hal lain, dan secara keseluruhan dengan struktur dengan tujuan tertentu. Dalam taksonomi Bloom, ranah kemampuan menganalisis digunakan dalam menyususn level kemampuan pembelajaran. Tindakan menganalisis diartikan sebagai tindakan menguraikan suatu permasalahan yang dihasilkan dari data menjadi beberapa bagian. Selanjutnya mengkonstruksikan bagian itu dalam suatu hubungan yang bermakna dan bermanfaat. Dalam sains, peserta didik akan mampu melihat mana faktor atau kondisi yang menjadi akibat dari beberapa faktor lain.

Berdasarkan uraian dan konsep yang telah dijelaskan, maka yang dimaksud dengan kemampuan menganalisis adalah kemampuan memecahkan masalah dengan cara menguraikan atau mengkonstruksikan sehingga mudah dicari solusinya. Dalam proses menganalisis, kemampuan peserta didik yang dikembangkan meliputi; membedakan fakta dan opini, menghubungkan kesimpulan dengan pernyataan-pernyataan pendukung, membedakan materi yang relevandengan yang tidak relevan, menghubungkan ideide, membedakan ide pokok dan ide turunan, menemukan bukti pendukung tujuan pengarang.

\section{METODE PENELITIAN}

Penelitian ini merupakan penelitian deskriptif kualitatif. Penelitian ini mengumpulkan informasi tentang kemampuan siswa SMA kelas XI di kabupaten Bengkulu Tengah sebagai populasi.

\section{Waktu dan Tempat Penelitian}

Penelitian dilaksanakan di SMA kelas XI wilayah Kabupaten Bengkulu Tengah terhadap HOTS dalam taksonomi menganalisis.

\section{Subjek Penelitian}

Populasi penelitian ini adalah siswa yang berada di SMA Kabupaten Bengkulu Tengah kelas XI IPA. Jumlah 
sekolah SMA di Bengkulu Tengah seluruhnya ada lima sekolah. Jumlah responden sebanyak 148 siswa. Jumlah tersebut adalah jumlah keseluruhan siswa yang ada di kabupaten Bengkulu Tengah.

\section{Prosedur}

Prosedur yang akan dilakukan dalam pembuatan instrumen HOTS sebagai berikut.

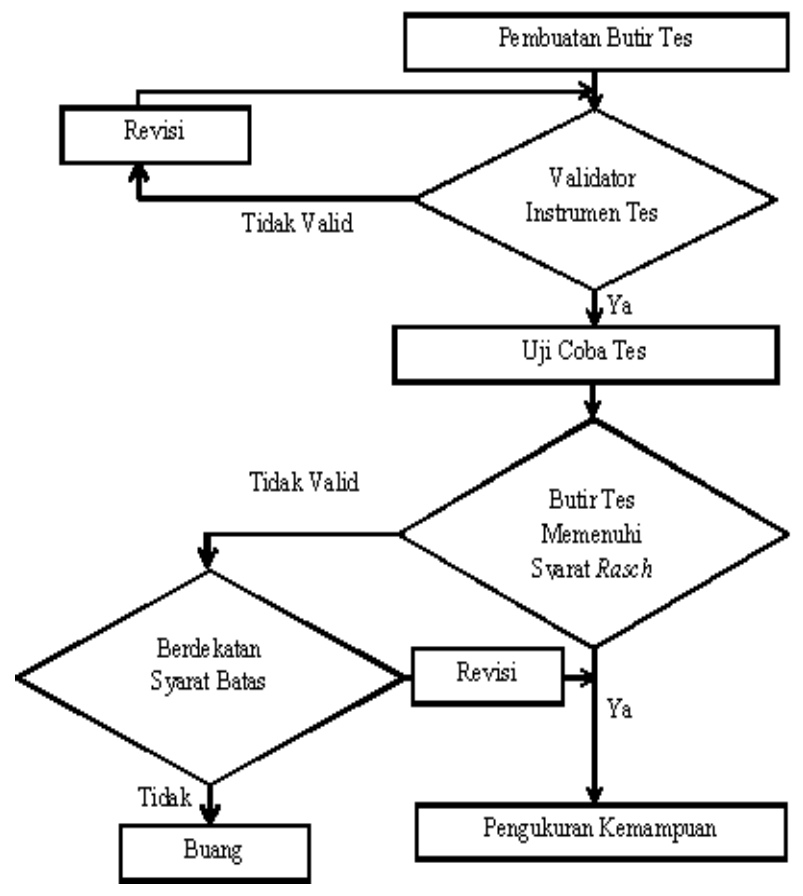

Gambar 1. Model Pembuatan Instrumen HOTS

Pada saat melakukan penelitian, hal yang akan dilakukan adalah (1) merancangan instrumen tes awal, (2) uji coba instrumen tes, dan (3) dan pengukuran. Secara rinci desain penelitian dirancang sebagai berikut: (1) menentukan tujuan pengukuran HOTS yang memenuhi syarat HOTS dalam fisika, (2) menentukan kompetensi Inti sekaligus menentukan kompetensi dasar dalam kurikulum 2013 akan digunakan sebagai acuan untuk membuat kisi-kisi butir tes, (3) menulis butir tes berdasarkan kisi-kisi yang telah dirancang. setiap satu indikator minimal membuat butir tes sebanyak tiga butir tes, (4) melakakukan validasi yang dilakukan oleh dua orang ahli dalam bidang fisika, (5) melakukan revisi butir tes yang belum baik dan menggabungkannya dalam butir tes yang sudah baik untuk dilakukan penelitian, (6) melakukan uji coba instrumen tes pada empat di kelas XI SMA Bengkulu Tengah, (7) melakukan analisis menggunakan aplikasi winstep, (8) melakukan revisi atau mengugurkan pada butir tes yang kurang baik serta menyusun butir tes yang akan digunakan pengukuran HOTS, (9) melakukan pengukuran pada siswa di lima sekolah dengan tujuh kelas, (10) melakukan analisis menggunakan aplikasi winsteps, dan (11) menginterpretasikan hasil pengukuran dan menyimpulkan hasil pengukuran mengenai HOTS kelas XI SMA di Kabupaten Bengkulu Tengah.

\section{Data, Intrumen, dan Teknik Pengumpulan Data \\ Teknik serta instrumen} pengumpulan data berupa perangkat tes. Data yang terkumpul akan diinput ke dalam Excel kemudian dikonversikan ke dalam notepad. Data yang telah diperoleh beserta jawaban diberikan skor dengan empat kategori, yaitu 1,2,3, atau 4 .

Berdasarkan format notepad berupa huruf yang berupa "A,B,C,D, dan seterusnya" merupakan kode siswa. Tanda berupa angka merupakan hasil skor yang diperoleh oleh siswa. Penentuan skor siswa mengacu pada penskoran politomus dengan empat kategori berikut: Skor 4: siswa mampu menjawab pilihan jawaban dengan benar dan idak mampu memberi pilihan alasan dengan benar.

Skor 3: siswa tidak mampu menjawab pilihan jawaban dengan benar dan mampu memberi pilihan alasan dengan benar.

Skor 2: siswa mampu menjawab pilihan jawaban dengan benar dan tidak mampu memberi pilihan alasan dengan benar.

Skor 1: siswa mampu menjawab pilihan jawaban dengan benar dan tidak mampu memberi pilihan alasan dengan benar. 
Instrumen dalam penelitian ini menggunakan instrumen berupa tes. Instrumen tes berbentuk soal tes sebagai instrumen alat ukur kemampuan siswa mengenai HOTS meliputi: 1) kisi-kisi instrumen, Kisi-kisi instrumen dijadikan panduan untuk menulis item butir tes menjadi tes. Tujuan penyusunan kisi-kisi tes adalah membatasi ruang lingkup dan tekanan penilaian yang tepat dan akurat sehingga dapat dijadikan sebagai panduan dalam menulis butir tes, 2) perangkat tes dan lembar jawaban, Naskah perangkat tes berupa butir soal pilihan ganda beralasan dengan lima pilihan alternatif pilihan jawaban.

Jumlah tes yang akan diujikan dalam tahap uji coba sebanyak 50 butir tes sedangkan yang digunakan dalam pengukuran sebanyak 36 butir tes. Lembar jawaban merupakan naskah yang digunakan siswa untuk menjawab butir tes yang telah diberikan sebelumnya. Lembar jawaban dikumpulkan atau diperoleh melalui tes terhadap lima sekolah dari siswa, dan 3) lembar validasi, Lembar lembar validasi yang perlu dinilai meliputi aspek konstruksi, aspek bahasa, dan aspek materi. Lembar validasi ini dibagikan kepada dua orang validator yang akan menentukan validasi tes secara teoritis. validator tes berasal dari ahli fisika yang ditentukan oleh program studi.

\section{Teknik Analisis Data}

Analisi data yang diterapkan adalah mencari validasi, reliabilitas, tingkat kesukaran, dan normalitas pada uji coba empiris. Guna memudahkan analisis, data analisis penelitian dianalisis dengan menggunakan bantuan komputer program Microsoft Exel Office 2010, SPSS, dan winstep3.73.

Analisis data kualitatif dilakukan oleh validator ahli mengnai butir tes yang dilihat dari segi materi, konstruksi, dan bahasa. Validasi isi ini dilakukan sebelum butir tes digunakan. Lembar jawaban siswa yang telah dikoreksi akan dianalisis secara kuantitatif. Analisis kuantitatif menggunakan skala polinomius dengan model rasch. Data yang telah dimasukkan dalam format dan susunan notepad dianalisis menggunakan program winsteps dan excel 2010. Berdasarkan hasil analisis hasil uji coba, diperoleh ukuran butir tes, sehingga dilakukan perbaikan setiap butir tes yang dirasa kurang cocok dak kurang valid. Berdasarkan data analisis akan mendapatkan, (1) butir-butir tes yang tidak fit dan yang fit, (2) reliabilitas, (3) kurva karekteristik, (4) tingkat kesukaran, dan normalitas.

Pengujian fit dilakukan pada analisis skor politomus dengan empat skala. Pengujian fit untuk tes secara keseluruhan maupun tiap butir tes dilakukan menggunakan program winsteps. Berdasarkan analisis Rasch Model didasarkan pada Outfit Mean Square (MNSQ), Outfit Z-Standard (ZSTD), dan nilai Point Measure Correlation (Pt Mean Corr). Rentang nilai yang fit berdasarkan MNSQ adalah $0,5<M N S Q<1,5$, Outfit Z-Standard adalah -2,00 $<$ ZSTD $<+2,00$, dan Point Measure Correlation (Pt Mean Corr) adalah 0,4 < Pt Mean Corr <0,85. Kreteria keputusannya adalah apabila butir tes tersebut minimal memenuhi dua kreteria yang telah ditentukan, maka butir tes tersebut dinyatakan valid.

Kurva karakteritik setiap buti tes atau Item Characteristic Curve (ICC) dapat dilihat dari graphs (expect score ICC) pada program winsteps. Setelah dianalisis maka akan menghasilkan kurva karakteristik. expect score ICC menunjukan bahwa garis yang berwarna merah merupakan garis ideal regresi logistic dan kurva yang berwarna biru merupakan kurva ruang kepercayaan sehingga dapat dilihat apabila butir tes misfit akan keluar dari kurva kepercayaan.

Tingkat kesukaran merupakan karakteristik yang akan digunakan dalam menentukan indeks kesukaran. Dengan memanfaatkan analisis menggunakan 
program winsteps diperoleh indeks kesukaran dengan cara meihat measure pada tampilan winsteps. Kesimpulan dalam melihat tingkat kesukaran mengacu pada soal dianggap baik, yaitu soal-soal sedang adalah soal-soal yang memiliki indeks kesukaran 0,30 sampai dengan 0,07 '.

Uji normalitas digunakan untuk menguji kenormalan pada data validasi instrument tes. Data yang dianggap baik salah satu cirinya adalah data yang berdistribusi normal. Irianto (2012) mengatakan bahwa yang dimaksud normalitas adalah salah satu metode yang digunakan untuk menunjukan bahwa penyebaran data yang diambil dalam sebuah sampel penelitian mewakili populasi, apabila sampel yang diambil tidak berdistribusi normal maka penarikan kesimpulan menjadi salah.

Freud \& Wilson, (2003) menyetakan bahwa traf signifikan pada umumnya yang digunakan untuk nomalitas adalah 0,05 , apabila signifikansi yang didapatkan lebih dari atau sama dengan 0,05 maka data tersebut berdistribusi normal.

Pada analisis data pengukuran kemampuan siswa dianalisis menggunakan program Microsoft Excel yang nantinya akan terbagi menjadi lima kategori kreteria. Penetapan standar kelulusan atau standar pencapaian kompetensi mengunakan standar yang diadaptasi dari tanwey adalah 60\%, maka acuan yang dapat digunakan $90 \% \leq$ $x$ maka "A (sangat tinggi)", $75 \% \leq x<90$ maka "B (tinggi)", $60 \% \leq x<75 \%$ maka "C ( sedang)", $40 \% \leq x<60 \%$ maka "D (rendah)", dan jika $x<40 \%$ maka "E (sangat rendah)".

\section{HASIL DAN PEMBAHASAN}

Hasil pengukuran HOTS pada taksonomi menganalisis terdiri dari 148 siswa sebagai populasi, dengan jumlah sekolah sebanyak lima sekolah. Kemampuan menganalisis dalam hasil penelitian ini digolongkan menjadi lima tingkatan, yaitu: sangat tinggi, tinggi, sedang, rendah, dan sangat rendah.

Hasil pengukuran HOTS ini adalah mengetahui Highest Level siswa dalam taksonomi menganalisis. Hasil yang didapatkan dalam pengukuran antara lain berdasarkan asal sekolah, dan berdasarkan ranah kognitif taksonomi Bloom (C4) yang meliputi kemampuan membedakan, kemampuan mengorganisir, dan kemampuan mengatribusikan. setelah melakukan pengukuran, akan memberikan masukan dan diiharapkan dapat memperbaiki HOTS pada sistem pembelajaran.

Pengukuran HOTS taksonomi menganalisis terbagi menjadi kemampuan membedakan, kemampuan mengorganisir, dan kemampuan mengatribusikan. Hasil penelitian siswa terhadap HOTS di Kabupaten Bengkulu Tengah menghasilkan skor rata-rata sebesar 70 . Skor tersebut menunjukan bahwa siswa kelas XI IPA SMA di kabupaten Bengkulu Tengah dikategorikan dalam kategori sedang. Pada ranah membedakan, mengurutkan, dan mengatribusikan, masing-masing, yaitu $33,19 \%, 33,71 \%$, dan 33, $09 \%$.

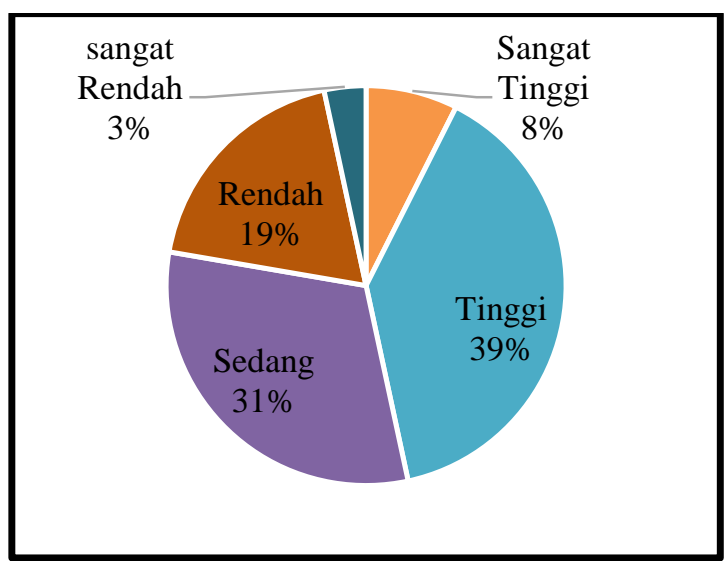

Gambar 2. Persentase kemampuan siswa dalam menganalisis berdasarkan indikator kemampuan membedakan 


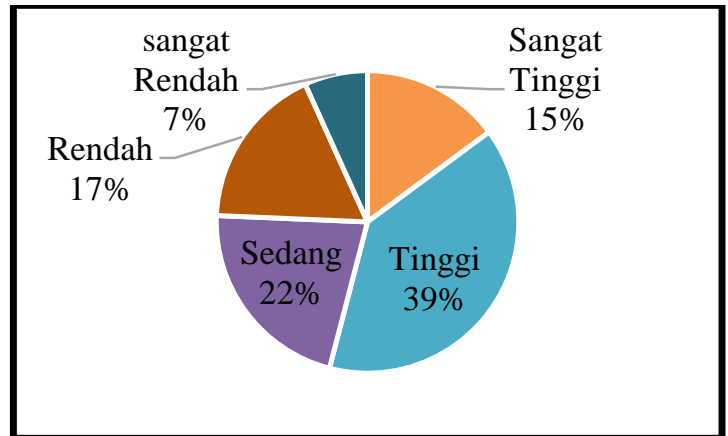

Gambar 3. Persentase kemampuan siswa dalam menganalisis berdasarkan indikator kemampuan mengurutkan

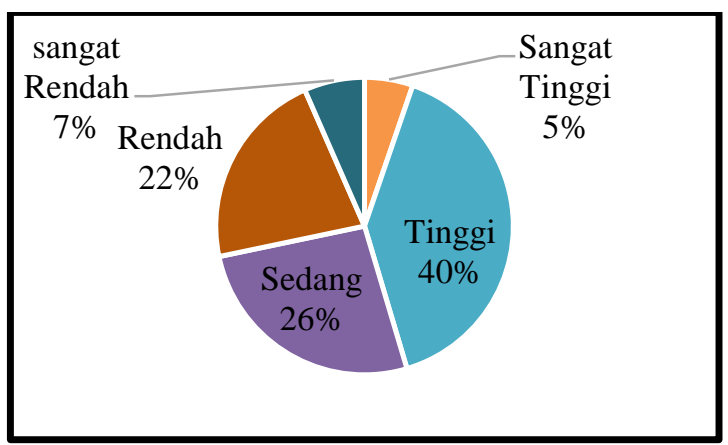

Gambar 4. Persentase kemampuan siswa dalam menganalisis berdasarkan indikator kemampuan mengatribusikan

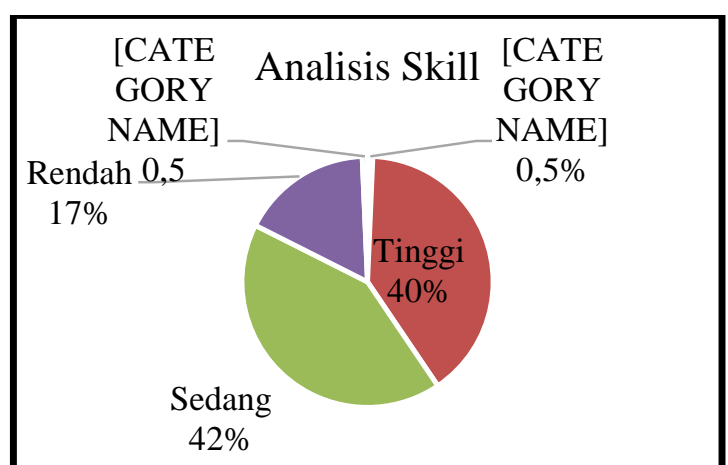

Gambar 5. Hasil Kemampuan siswa dalam Menganalisis yeng meliputi kemampuan membedakan, mengurutkan, dan mengatribusikan

Berdasarkan Gambar 2 dapat dilihat bahwa siswa yang memiliki HOTS yang termasuk kategori sangat tinggi adalah 11 siswa atau $8 \%$, termasuk kategori tinggi 58 siswa atau $39 \%$, termasuk kategori Sedang 46 siswa atau $31 \%$, termasuk Kategori Rendah 28 siswa atau $19 \%$, Kategori sangat Rendah 5 siswa atau $3 \%$.
Berdasarkan Gambar 3 dapat dilihat bahwa siswa yang memiliki HOTS yang termasuk kategori sangat tinggi adalah 22 siswa atau $15 \%$, termasuk kategori tinggi 58 siswa atau $39 \%$, termasuk kategori Sedang 32 siswa atau $22 \%$, termasuk Kategori Rendah 26 siswa atau $17 \%$, Kategori sangat Rendah 10 siswa atau 7 $\%$.

Berdasarkan Gambar 4 dapat dapat dilihat bahwa siswa yang memiliki HOTS yang termasuk kategori sangat tinggi adalah 8 siswa atau 5\%, termasuk kategori tinggi 61 siswa atau $40 \%$, termasuk kategori Sedang 40 siswa atau $26 \%$, termasuk Kategori Rendah 33 siswa atau $22 \%$, Kategori sangat Rendah 6 siswa atau $7 \%$.

HOTS dalam taksonomi menganalisis secara keseluruhan berdasarkan kemampuan membedakan, mengurutkan, dan mengatribusikan dapat dilihat pada gambar 5. Berdasarkan gambar tersebut, siswa yang memiliki kemampuan menganalisis sangat tinggi 1 siswa atau $0,5 \%$, kemampuan menganalisis tinggi 59 siswa atau $40 \%$, kemampuan menganalisis sedang 62 siswa atau 42\%, kemampuan menganalisis rendah 25 siswa atau $17 \%$, kemampuan menganalisis sangat rendah 1 siswa atau $0,5 \%$.

Dari kemampuan membedakan, mengurutkan, dan mengatribusikan dalam hasil penelitian yang digolongkan menjadi lima tingkatan, yaitu: sangat tinggi, tinggi, sedang, rendah, dan sangat rendah maka secara umum siswa paling banyak hanya memiliki kemampuan sedang dalam menaganalisis permasalahan fisika.

Hal tersebut disebabkan oleh sistem pembelajaran yang mirip yaitu menggunakan ceramah, penugasan, dan catatan. Dari kemampuan membedakan, mengurutkan, dan mengatribusikan siswa banyak memahami pada ranah mengurutkan, yaitu sebanyak 33,71\%. Sedangkan menganalisis paling sulit 
berada pada ranah mengatribusikan, yaitu 33, $09 \%$.

Perbedaan hasil yang tidak signifikan disebabkan oleh sistem pembelajaran yang mirip yaitu menggunakan ceramah, penugasan, dan catatan. Selain itu, pembelajaran yang paling sering digunakan adalah ingatan (C1), pemahaman (C2), dan aplikasi (C3). Hal tersebut yang menyebabkan kemampuan siswa belum terbiasa dalam hight order thinking khususnya berpikir kritis. Sesuai dengan pendapat Kuswana (2011) bahwa kegiatan yang menggunakan dan membiasakan kerja otak untuk menempatkan keahliannya yang meliputi analisis, menyimpulkan, dan evaluasi akan mudah dalam mengasah HOTS dalam diri individu.

Selain belum terbiasanya menggunakan HOTS, faktor lain yang menyebabkan siswa masih dalam kreteria sedang adalah budaya dan karakter. Dari kelima sekolah tersebut terletak dalam kecamatan yang berbeda, dan suku berbeda. Dari budaya tersebut akan membedakan pola berpikir para siswa. Lichona (2012) secara umum budaya diturunkan dari orang tua dan anak, sehingga apa yang orang tua alami akan membentuk kepribadian anak, maka bertahun tahun kebiasaan dan budaya tersebut akan melekat. Dari itu baik dan buruknya yang dilakukan anak sebagai individu dipengaruhi oleh budaya yang berlaku di lingkungan. Lebih lanjut secara sains Zuchdi (2011) mengungkapkan bahwa kemampuan sains siswa akan meningkat baik secara prinsip dan konsep apabila lingkungan dan teknologi mendukung karena hal itu berkaitan dengan proses dasar sains dan proses terbuntuknya sains.

\section{SIMPULAN}

HOTS siswa kelas XI SMA di Kabupaten Bengkulu Tengah terhadap fisika secara keseluruhan didominasi dengan kemampuan sedang. Hasil pengukuran menunjukkan kemampuan menganalisis sangat tinggi 1 siswa atau $0,5 \%$, kemampuan menganalisis tinggi 59 siswa atau 40\%, kemampuan menganalisis sedang 62 siswa atau $42 \%$, kemampuan menganalisis rendah 25 siswa atau $17 \%$, kemampuan menganalisis sangat rendah 1 siswa atau $0,5 \%$.

\section{DAFTAR PUSTAKA}

Anderson, L.W., \& Krathwohl, D.R. (2010). Kerangka landasan untuk pembelajaran, pengajaran, dan asesmen (terjemahan Agung Prihantoro). New York: Addition Wesley Longman. (buku asli diterbitkan tahun 2001).

Arwood, E.L. (2011). Language

Function an Introduction to

Pragmatic Assessment and

Intervention for Higher Order

Thinking and Better Literacy.

Philadelphia: Jessica Kingsley

Publishers.

Bloom, B. S. (1956). Taxonomy of Education Objectives Handbook I: Cognitive Domain. New York : David MsKay.

Bogan, Y. K.H., \&Porter, R.C. (2005). On the Ball with Higher-Order Thinking. ProQuest Research Library, 36, 46-47.

Brookhart, S.M. (2010) Assess higherorder thingking skills in your classroom. Alexandria : ASCD.

Costa, Arthur L. (1991). Developing Minds: Programs for Teaching Thinking (Rev.Ed). Volume 2. Alexandria : ASCD.

Derry, G.N. (1999). What Science is and How it Works. New Jersey: Princeton University Press.

Freud \& Wilson. (2003). Statistical Methods. London: Academic Press. 
Irianto, Agus. (2012). Statistik : Konsep Dasar, Aplikasi, dan Pengembangannya. Jakarta: Kencana.

Jennifer L., Mestre. J. P., \& Ross. B.H. (2012). Impact of a Short Intervention on Novices' Categorization Criteria [versi elektronik].. Physics Education Research, 8,1.

Gardner, Howard. (2013). Multiple Intelligences (terjemahanYelvi Andri Zaimul). New York: Basic Books. (buku asli terbitan tahun 2006).

Kohl, P. B., \& Finkelstein. N.D. (2008). Patterns of Multiple Representation Use by Experts and Novices During Physics Problem Solving [versi elektronik]. Physics Education Research, 4, 11-12

Krathwohl, D. R. (2002). A Revision of Bloom's Taxonomy: An Overview [versi elektronik]. Theory into Practice, 41, 2014.

Kuswana.W.S. (2013). Taksonomi Berpikir. Bandung: Rosda Karya.

Lichona, Thomas. (2012). Mendidik untuk Membentuk Karakter (terjemahan juma abdu wamungo). New York: (buku asli diterbitkan tahun 1989).

Miri, Barak., \& David, B.C., \& Uri, Zoller. (2007). Purposely Teaching for the Promotion of Higher- order Thinking Skills: A Case of Critical Thinking. Springer Science. 37,366.

Nitko, A.J., \& Brookhart, S.M. (2011). Educational assessment of students $\left(6^{r d}\right.$ ed.). Boston : Pearson

OECD. PISA (Programme for International Student Assessment. [online]. Tersedi: https://www.oecd.org/pisa/data/ 7 desember 2016]
Rianawati. Ida (2011). Berfikir Tingkat Tinggi (Higher Order Thinking). [Online]. Tersedia: http://idarianawaty.blogspot.com/20 11/08/berpikir-tingkat-tinggihigher-order.html $\quad[14$ Februari 2014]

TIMSS \& PIRL. (2016). Trends International Mathematics and Science Study. Tersedia di https://timssandpirls.bc.edul

Williams, J.D. (2011). How Science Works Teaching and Learning in the Science Classroom. British :Continum.

Zuchdi, Darmiyati (2011). Pendidikan Karakter Dalam Persepektif Teori dan Praktik. Yogyakarta: UNY press 